\title{
Thalassospira tepidiphila sp. nov., a polycyclic aromatic hydrocarbon-degrading bacterium isolated from seawater
}

Correspondence

Kazuya Watanabe

kazuya.watanabe@mbio.jp

\author{
Yumiko Kodama, ${ }^{1,2}$ Lies Indah Stiknowati, ${ }^{3}$ Atsuko Ueki, ${ }^{2}$ Katsuji Ueki ${ }^{2}$ \\ and Kazuya Watanabe ${ }^{1}$
}

\author{
${ }^{1}$ Laboratory of Applied Microbiology, Marine Biotechnology Institute, 3-75-1 Heita, Kamaishi, \\ Iwate 026-0001, Japan \\ ${ }^{2}$ Faculty of Agriculture, Yamagata University, Wakaba-machi 1-23, Tsuruoka 997-8555, Japan \\ ${ }^{3}$ Research Center for Oceanography Indonesian Institute of Science, JI. Pasir Putih I No. 1, \\ Ancol Timur, Jakarta Utara 14430, Indonesia
}

\begin{abstract}
A Gram-negative, mesophilic bacterial strain, designated $1-1 \mathrm{~B}^{\top}$, which degrades polycyclic aromatic hydrocarbons, was isolated from petroleum-contaminated seawater during a bioremediation experiment. A 16S rRNA gene sequence analysis indicated that the isolate was affiliated with the genus Thalassospira in the Alphaproteobacteria; the sequence was found to be most similar to those of Thalassospira profundimaris WP0211 ${ }^{\top}(99.8 \%)$, Thalassospira xiamenensis $\mathrm{M}-5^{\top}(98.2 \%)$ and Thalassospira lucentensis DSM $14000^{\top}$ (98.1\%). However, the levels of DNA-DNA relatedness between strain $1-1 \mathrm{~B}^{\top}$ and these type strains were $50.7 \pm 17.2$, $35.7 \pm 17.8$ and $32.0 \pm 21.1 \%$, respectively. In addition, strain $1-1 \mathrm{~B}^{\top}$ was found to be distinct from the other described species of the genus Thalassospira in terms of some taxonomically important traits, including DNA G +C content, optimum growth temperature, salinity tolerance, utilization of carbon sources and fatty acid composition. Furthermore, strain $1-1 \mathrm{~B}^{\top}$ and $T$. profundimaris were also different with regard to motility and denitrification capacities. On the basis of physiological and DNA-DNA hybridization data, strain $1-1 \mathrm{~B}^{\top}$ represents a novel species within the genus Thalassospira, for which the name Thalassospira tepidiphila sp. nov. is proposed. The type strain is $1-1 \mathrm{~B}^{\top}\left(=\mathrm{JCM} 14578^{\top}=\mathrm{DSM} 18888^{\top}\right)$.
\end{abstract}

The genus Thalassospira was proposed by López-López et al. (2002). At the time of writing, the genus includes three species: Thalassospira lucentensis, the type species of the genus (López-López et al., 2002), T. xiamenensis and T. profundimaris (Liu et al., 2007). T. xiamenensis $\mathrm{M}-5^{\mathrm{T}}$ and T. profundimaris $\mathrm{WP} 0211^{\mathrm{T}}$ were isolated from a bacterial consortium growing on hydrocarbons as carbon sources, but neither strain was able to degrade hydrocarbons in pure culture (Liu et al., 2007). We recently isolated several bacterial strains affiliated with the genus Thalassospira from oil-contaminated seawater and found that they could degrade several polycyclic aromatic hydrocarbons (PAHs), including naphthalene, dibenzothiophene, phenanthrene and fluorene (unpublished). We now consider that these strains play important roles in marine spilled-oil bioremediation. In this communication, we report on the

Abbreviation: $\mathrm{PAH}$, polycyclic aromatic hydrocarbon.

The GenBank/EMBL/DDBJ accession number for the 16S rRNA gene sequence of strain $1-1 B^{\top}$ is $A B 265822$. polyphasic taxonomic characterization of one of our $\mathrm{PAH}$-degrading isolates, strain $1-1 \mathrm{~B}^{\mathrm{T}}$, which is affiliated with the genus Thalassospira.

Strain $1-1 B^{T}$ was isolated from petroleum-contaminated seawater during a bioremediation experiment described previously (Kasai et al., 2002). Seawater was collected from a bioremediation tank, serially diluted and spread onto $1 \%$ $(\mathrm{w} / \mathrm{v})$ Gelrite plates containing the artificial seawater medium ONR7a (Dyksterhouse et al., 1995). The plates were then coated with heat-treated Arabian light crude oil $(0.2 \%, w / v)$ (Kasai et al., 2002) and incubated at $20{ }^{\circ} \mathrm{C}$. After incubation for 3 weeks, small colonies appearing on these plates were picked and streaked onto solid plates containing marine broth 2216 (MB; Difco) and $1 \%$ (w/v) Gelrite for purification. $\mathrm{MB}$ was used for routine cultivation. To monitor growth, cell concentrations were determined from the direct counting of 4',6-diamino-2phenylindole-stained cells under an epifluorescence microscope, as described by Kodama \& Watanabe (2003). Cells of strain $1-1 \mathrm{~B}^{\mathrm{T}}$ were stored at $-80{ }^{\circ} \mathrm{C}$ in $\mathrm{MB}$ supplemented with $15 \%(\mathrm{v} / \mathrm{v})$ glycerol. 
The ability of strain $1-1 \mathrm{~B}^{\mathrm{T}}$ to degrade PAHs was examined in ONR7a medium supplemented with a mixture of heattreated Arabian light crude oil $\left(100 \mathrm{mg} \mathrm{l}^{-1}\right)$ and three compounds, namely phenanthrene, pyrene and benzo[a] pyrene ( $1 \mathrm{mg} \mathrm{l}^{-1}$ in each case). To prepare an inoculum, cells of strain $1-1 \mathrm{~B}^{\mathrm{T}}$ were grown in $\mathrm{MB}$ for 2 days at $30{ }^{\circ} \mathrm{C}$ and harvested by centrifugation $(8000 \mathrm{~g}$ for $10 \mathrm{~min})$. Duplicate aliquots of the medium $(10 \mathrm{ml})$ were prepared in $50 \mathrm{ml}$ vials, inoculated with cells and sealed with Tefloncoated butyl rubber septa and crimped aluminium caps and then incubated at $30{ }^{\circ} \mathrm{C}$ with shaking. Aliquots of noninoculated medium were incubated similarly and served as controls. After incubation for 11 days, oil components were extracted with chloroform and quantitatively analysed using GC-MS (GC-MS-QP5000; Shimadzu) as described elsewhere (Kasai et al., 2002). The proportion (\%) of the initial amount that was biodegraded was calculated as described by Dutta \& Harayama (2000). Strain $1-1 \mathrm{~B}^{\mathrm{T}}$ degraded $92.0 \pm 3.1 \%$ (mean $\pm \mathrm{SD}$ ) of $\mathrm{C}_{0}$-alkylnaphthalene, $97.4 \pm 0.4 \%$ of $\mathrm{C}_{1}$-alkylnaphthalene, $28.0 \pm 4.6 \%$ of $\mathrm{C}_{2}$ alkylnaphthalene, $84.5 \pm 9.0 \%$ of $\mathrm{C}_{0}$-alkyldibenzothiophene, $\quad 38.5 \pm 11.6 \%$ of $\mathrm{C}_{0}$-alkylphenanthrene and $73.0 \pm 10.6 \%$ of $\mathrm{C}_{0}$-alkylfluorene within 11 days, whereas significant degradation (more than $10 \%$ of initial amounts) was not observed for n-alkanes, $\mathrm{C}_{3-5}$-alkylnaphthalenes, $\mathrm{C}_{1-4}$-alkyldibenzothiophenes, $\mathrm{C}_{1-3}$-alkylphenanthrenes, $\mathrm{C}_{1-3}$-alkylfluorenes, pyrene or benzo[a]pyrene $\left(\mathrm{C}_{0}-\mathrm{C}_{5}\right.$ represent carbon numbers of the alkyl side chains in alkylated PAHs). When the medium was supplemented with naphthalene, dibenzothiophene, phenanthrene or fluorene as the sole carbon source, strain $1-1 \mathrm{~B}^{\mathrm{T}}$ degraded naphthalene $(44.6 \pm 20.2 \%)$ and fluorene $(17.1 \pm 3.5 \%)$, but did not degrade phenanthrene or dibenzothiophene within 11 days.

Cell morphology was examined by means of transmission and scanning electron microscopy (Beveridge et al., 1994). Motility was checked using phase-contrast microscopy. Gram staining and oxidase and catalase tests were conducted according to standard procedures (Smibert \& Krieg, 1994). The optimal growth temperature and $\mathrm{pH}$ were determined in $\mathrm{MB}$ and salinity requirements were examined using modified MB (Sohn et al., 2004). Nitrate reduction and denitrification were examined using ONR7a supplemented with $\mathrm{NaNO}_{3}(5 \mathrm{mM})$ as an electron acceptor and sodium acetate $(10 \mathrm{mM})$ as an electron donor. After the medium had been autoclaved, the following sterile solutions were added $\left(1^{-1}\right)$ under an oxygen-free $\mathrm{N}_{2}$ atmosphere: $5 \mathrm{ml}$ resazurin solution $\left(0.2 \mathrm{~g} \mathrm{l}^{-1}\right)$ as an oxidation-reduction indicator and $10 \mathrm{ml} \quad 4 \% \mathrm{TiCl}_{3}$ solution as a reducing agent (Kodama et al., 2007). Consumption of nitrate and nitrite was measured by ion chromatography using an ICA-2000 ion analyser equipped an electrolytic conductivity detector and a spectrophotometer (Toa DKK). For physiological and biochemical characterizations, API 20NE (bioMérieux) and Biolog GN2 microplates (Biolog) were used according to the manufacturers' instructions.
Strain $1-1 \mathrm{~B}^{\mathrm{T}}$ comprised cells that were Gram-negative, motile and vibrioid to spiral $(0.17-0.33 \mu \mathrm{m}$ wide and $0.9-$ $2.0 \mu \mathrm{m}$ long) in shape (Fig. 1). Cells were motile by means of single polar flagella (Fig. 1). The oxidase and catalase tests gave positive results. Growth of strain $1-1 \mathrm{~B}^{\mathrm{T}}$ was observed between 8 and $45{ }^{\circ} \mathrm{C}$, with an optimum at $43{ }^{\circ} \mathrm{C}$. Strain $1-1 \mathrm{~B}^{\mathrm{T}}$ grew at $\mathrm{pH} 5-10$, with an optimum at $\mathrm{pH} 7$. $\mathrm{NaCl}$ was essential for the growth of strain $1-1 \mathrm{~B}^{\mathrm{T}}$ : no growth was observed in medium lacking $\mathrm{NaCl}$. Growth occurred at $\mathrm{NaCl}$ concentrations of $2-14 \%$, with an optimum at $3 \%$. Nitrate was reduced to nitrite under anaerobic conditions, but nitrite was not reduced to nitrogen. The API $20 \mathrm{NE}$ test showed that strain $1-1 \mathrm{~B}^{\mathrm{T}}$ was positive for nitrate reduction but negative for indole production, glucose fermentation, arginine dihydrolase, urease, aesculin hydrolysis, gelatinase and $\beta$-galactosidase. The results from the Biolog test are given in the species description (see below).

The cellular fatty acids were analysed in the TechnoSuruga Laboratory (Shizuka, Japan) using cells grown in $\mathrm{MB}$ for $24 \mathrm{~h}$. The fatty acids present in strain $1-1 \mathrm{~B}^{\mathrm{T}}(\geqslant 0.1 \%)$ were as follows: $\mathrm{C}_{18: 1} \omega 7 c(41.73 \%), \mathrm{C}_{16: 0}(20.25 \%), \mathrm{C}_{17: 0}$ cyclo $(9.30 \%), \mathrm{C}_{14: 0}(4.81 \%), \mathrm{C}_{16: 1} \omega 7 c$ and/or iso- $\mathrm{C}_{15: 0}$ $2-\mathrm{OH}(4.67 \%), \mathrm{C}_{19: 0}$ cyclo $\omega 8 c(4.10 \%), \mathrm{C}_{16: 0} 3-\mathrm{OH}$ $(3.22 \%), \mathrm{C}_{18: 0}(2.09 \%), \mathrm{C}_{14: 0} 3-\mathrm{OH}$ and/or iso- $\mathrm{C}_{16: 1} \mathrm{I}$ (1.38\%), $\mathrm{C}_{18: 1} 2-\mathrm{OH}(1.22 \%), \mathrm{C}_{13: 1}(1.14 \%), \mathrm{C}_{16: 1} \omega 5 c$ (0.69\%), $\mathrm{C}_{18: 0} \quad 3-\mathrm{OH} \quad(0.63 \%), \quad 11$-methyl $\mathrm{C}_{18: 1} \omega 7 c$ $(0.50 \%), \quad \mathrm{C}_{12: 0} \quad(0.42 \%), \quad \mathrm{C}_{18: 1} \omega 5 c \quad(0.41 \%), \quad \mathrm{C}_{17: 0}$ $(0.37 \%), \mathrm{C}_{17: 1} \omega 8 c(0.28 \%), \mathrm{C}_{15: 0}(0.27 \%), 10$-methyl $\mathrm{C}_{19: 0} \quad(0.14 \%)$, anteiso- $\mathrm{C}_{17: 1} \omega 9 c \quad(0.11 \%), \mathrm{C}_{20: 1} \omega 7 c$ $(0.11 \%)$ and $\mathrm{C}_{17: 0} 3-\mathrm{OH}(0.10 \%)$. The major fatty acids of strain $1-1 \mathrm{~B}^{\mathrm{T}}$ were similar to those of members of the genus Thalassospira (López-López et al., 2002; Liu et al., 2007). However, the presence of a relatively large proportion of the fatty acid $\mathrm{C}_{17: 0}$ cyclo in $1-1 \mathrm{~B}^{\mathrm{T}}$ serves to distinguish the strain from Thalassospira species (Table 1).

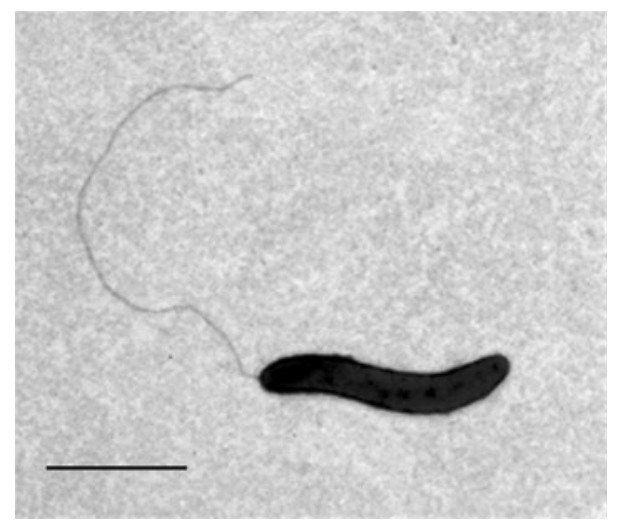

Fig. 1. Transmission electron micrograph of a cell of strain $1-1 B^{\top}$. Bar, $1 \mu \mathrm{m}$. 
Table 1. Characteristics that differentiate strain $1-1 B^{\top}$ from type strains of Thalassospira species

Strains: 1, 1-1B ${ }^{\mathrm{T}}$ (data from this study); 2, T. profundimaris $\mathrm{WP} 0211^{\mathrm{T}}$ (unless indicated otherwise, data were taken from Liu et al., 2007); 3 , T. xiamenensis $\mathrm{M}-5^{\mathrm{T}}$ (Liu et al., 2007); 4, T. lucentensis $\mathrm{QMT} 2^{\mathrm{T}}$ (López-López et al., 2002). +, Positive; -, negative; w, weakly positive; ND, no data available.

\begin{tabular}{|c|c|c|c|c|}
\hline Characteristic & 1 & 2 & 3 & 4 \\
\hline Motility & + & - & + & + \\
\hline Temperature range (optimum) $\left({ }^{\circ} \mathrm{C}\right)$ & $8-45(43)$ & $10-37(22)$ & $4-40(22)$ & $4-40(\mathrm{ND})$ \\
\hline $\mathrm{NaCl}$ range (optimum) (\%) & $2-14(3)$ & $2-8(3-4)$ & $0.5-10(2-4)$ & $2-10(\mathrm{ND})$ \\
\hline Reduction of nitrate to nitrite & + & $-{ }^{\star}$ & $+^{\star}$ & $+^{\star}$ \\
\hline \multicolumn{5}{|l|}{ Substrate utilization: $\dagger$} \\
\hline Tween 40 & + & + & - & $+^{*}$ \\
\hline Tween 80 & $\mathrm{w}$ & + & - & $\mathrm{W}^{*}$ \\
\hline$N$-Acetyl-D-glucosamine & - & - & + & $+^{*}$ \\
\hline L-Rhamnose & - & - & - & $+^{*}$ \\
\hline D-Saccharic acid & - & - & - & $+^{*}$ \\
\hline
\end{tabular}

${ }^{\star}$ Determined in this study.

$\dagger$ Based on the Biolog system.

A phylogenetic analysis based on 16S rRNA gene sequences was conducted as described by Watanabe et al. (2000), with the following modifications: amplification was performed using a PCR thermal cycler (Takara) and primers B27f and U1492r (Orphan et al., 2001) in a $50 \mu \mathrm{l}$ mixture containing 1.25 U KOD Dash DNA polymerase (Toyobo), $5 \mu \mathrm{l} 10 \times$ PCR buffer, $0.2 \mathrm{mM}$ each dNTP, 50 pmol each primer and 10 ng DNA. The PCR conditions used were as follows: 2 min activation of the polymerase at $96{ }^{\circ} \mathrm{C}$, followed by 35 cycles consisting of $15 \mathrm{~s}$ at $95{ }^{\circ} \mathrm{C}, 15 \mathrm{~s}$ at $50{ }^{\circ} \mathrm{C}$ and $30 \mathrm{~s}$ at $74{ }^{\circ} \mathrm{C}$, ending with $2 \mathrm{~min}$ extension at $74{ }^{\circ} \mathrm{C}$. The nucleotide sequences of the PCR products were determined using a BigDye terminator v3.1 cycle sequencing kit (Applied Biosystems) and a model 3730 DNA sequencer (Applied Biosystems). The software used to align the sequences was CLUSTAL W, version 1.7 (Thompson et al., 1994), and the alignments were refined by visual inspection. The phylogenetic dendrogram was constructed using the NJPlot program in CLUSTAL W, version 1.7. Phylogenetic analysis based on 16S rRNA gene sequences showed that 1$1 \mathrm{~B}^{\mathrm{T}}$ was affiliated with the genus Thalassospira (Fig. 2) and closely related to $T$. profundimaris WP0211 ${ }^{\mathrm{T}}(99.8 \%$ sequence similarity), T. xiamenensis $\mathrm{M}-5^{\mathrm{T}}(98.2 \%)$ and T. lucentensis DSM $14000^{\mathrm{T}}(98.1 \%)$. It has been reported that strains with $16 \mathrm{~S}$ rRNA gene sequence similarity of above $99 \%$ sometimes exhibit a DNA-DNA reassociation value below $70 \%$ (Stackebrandt \& Ebers, 2006). In this case, although strain $1-1 \mathrm{~B}^{\mathrm{T}}$ and $T$. profundimaris $\mathrm{WP} 0211^{\mathrm{T}}$ are fairly similar in their $16 \mathrm{~S}$ rRNA gene sequences $(99.8 \%$ identical), they showed some differences in phenotypic properties (e.g. in the ability to degrade PAHs, motility, growth temperature and salinity tolerance), prompting us to examine the DNA-DNA relatedness. Genomic DNA was extracted as described by Murray \& Thompson (1980) and then purified using caesium chloride density-gradient ultracentrifugation. DNA-DNA relatedness was determined in triplicate by the fluorometric hybridization method on a microdilution plate (Ezaki et al., 1989) in the TechnoSuruga Laboratory. Reverse hybridization was also conducted, again in triplicate. The levels of DNA-DNA relatedness between strain $1-1 \mathrm{~B}^{\mathrm{T}}$ and the type strains of Thalassospira species $(T$. profundimaris $\mathrm{WP} 0211^{\mathrm{T}}, T$. xiamenensis $\mathrm{M}-5^{\mathrm{T}}$ and $T$. lucentensis CECT $5390^{\mathrm{T}}$ ) were $50.7 \pm 17.2,35.7 \pm 17.8$ and $32.0 \pm 21.1 \%$, respectively (means $\pm \mathrm{SD}, n=6$ ). The DNA $\mathrm{G}+\mathrm{C}$ content of strain $1-1 \mathrm{~B}^{\mathrm{T}}$, as determined using the method of Katayama-Fujimura et al. (1984), was $55.1 \pm 0.4 \operatorname{mol} \%($ mean $\pm \mathrm{SD}, n=3)$.

Features of strain $1-1 \mathrm{~B}^{\mathrm{T}}$ that differentiate it from recognized Thalassospira species are shown in Table 1. The ability of the Thalassospira type strains to reduce nitrate was examined in this study, and the Biolog test was applied to T. lucentensis CECT $5390^{\mathrm{T}}$. Although strain 1$1 \mathrm{~B}^{\mathrm{T}}$ and $T$. profundimaris $\mathrm{WP} 0211^{\mathrm{T}}$ are fairly similar in terms of their $16 \mathrm{~S}$ rRNA gene sequences (99.8\% similarity), they differ with regard to some physiological and taxonomic properties, i.e. growth temperature, salinity tolerance, nitrate reduction and $\mathrm{G}+\mathrm{C}$ content (Table 1). Strain $1-1 \mathrm{~B}^{\mathrm{T}}$ differed from $T$. xiamenensis $\mathrm{M}-5^{\mathrm{T}}$ in its denitrification abilities and substrate utilization, and it differed from $T$. lucentensis CECT $5390^{\mathrm{T}}$ in its substrateutilization pattern and major fatty acids. In addition, strain 


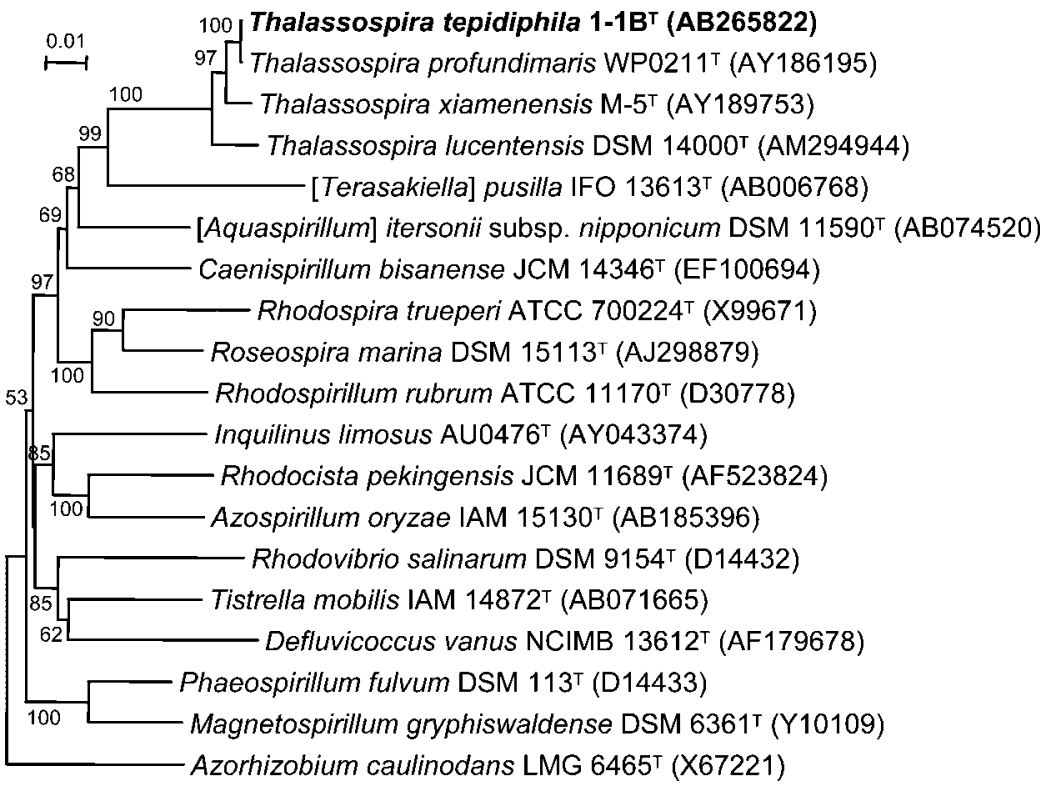

Fig. 2. Neighbour-joining phylogenetic dendrogram, based on 16S rRNA gene sequence comparisons, showing the position of strain 1$1 \mathrm{~B}^{\mathrm{T}}$ and related genera within the family Rhodospirillaceae. The sequence of Azorhizobium caulinodans LMG $6465^{\top}$ was used as the outgroup. Accession numbers of sequences are given in parentheses. Numbers at branch nodes are bootstrap values (per 100 trials); only values greater than 50 are shown. Bar, 0.01 substitutions per site.
$1-1 B^{T}$ is the only one of these strains that can degrade PAHs. The DNA-DNA relatedness values for strain $1-1 \mathrm{~B}^{\mathrm{T}}$ with respect to the three Thalassospira type strains were significantly below $70 \%(P<0.01$, as assessed with a $t$-test $)$. On the basis of these physiological and chemotaxonomic properties, together with the DNA-DNA relatedness values (Wayne et al., 1987), strain $1-1 \mathrm{~B}^{\mathrm{T}}$ is distinguishable from the recognized Thalassospira species and represents a novel species of the genus Thalassospira, for which the name Thalassospira tepidiphila sp. nov. is proposed.

\section{Description of Thalassospira tepidiphila sp. nov.}

Thalassospira tepidiphila (te.pi.di.phi'la. L. adj. tepidus lukewarm; Gr. adj. philos loving; N.L. fem. adj. tepidiphila lukewarm-loving, mesophilic).

Cells are Gram-negative, vibrioid to spiral, $0.17-0.33 \mu \mathrm{m}$ wide and $0.9-2.0 \mu \mathrm{m}$ long. Cells are motile by means of single polar flagella. Colonies on MB Gelrite are smooth, convex, opaque and slightly yellow. Oxidase- and catalasepositive. In the API 20NE test, negative for glucose fermentation, arginine dihydrolase and gelatinase activity. $\mathrm{NaCl}$ is required for growth; optimum growth occurs with $3 \% \mathrm{NaCl}$ and the range is $2-14 \%$. The optimum growth temperature is $43{ }^{\circ} \mathrm{C}$ (range, $8-45^{\circ} \mathrm{C}$ ) and the optimum $\mathrm{pH}$ is 7.0 (range, $\mathrm{pH}$ 5.0-10.0). Facultatively anaerobic; nitrate is reduced to nitrite under anaerobic conditions, but nitrite is not reduced to nitrogen (nitrite is the final product of nitrate reduction). In Biolog GN2 plates, the following are utilized as carbon sources: Tween 40, Larabinose, D-arabitol, cellobiose, D-fucose, D-galactose, $\alpha$ D-glucose, myo-inositol, D-mannitol, D-mannose, methyl pyruvate, acetic acid, cis-aconitic acid, citric acid, Dglucosaminic acid, D-glucuronic acid, $\beta$-hydroxybutyric acid, $\gamma$-hydroxybutyric acid, $\alpha$-ketoglutaric acid, DL-lactic acid, quinic acid, succinic acid, bromosuccinic acid,
D-alanine, L-alanine, L-asparagine, L-aspartic acid, Lglutamic acid, glycyl L-aspartic acid, glycyl L-glutamic acid, L-histidine, hydroxy-L-proline, L-proline, L-pyroglutamic acid, L-serine, $\gamma$-aminobutyric acid, urocanic acid and glycerol. The following are utilized weakly: glycogen, Tween 80, D-psicose, formic acid, D-galactonic acid lactone, D-galacturonic acid, D-gluconic acid, malonic acid, propionic acid, succinamic acid and L-alanyl glycine. Degrades naphthalene, phenanthrene, dibenzothiophene and fluorene (mixed into crude oil). The major cellular fatty acids are $\mathrm{C}_{18: 1} \omega 7 c, \mathrm{C}_{16: 0}$ and $\mathrm{C}_{17: 0}$ cyclo. The genomic DNA $\mathrm{G}+\mathrm{C}$ content of the type strain is $55.1 \pm 0.4 \mathrm{~mol} \%$.

The type strain, $1-1 \mathrm{~B}^{\mathrm{T}}\left(=\mathrm{JCM} 14578^{\mathrm{T}}=\mathrm{DSM} 18888^{\mathrm{T}}\right)$, was isolated from petroleum-contaminated seawater in a beachsimulation tank during a bioremediation experiment.

\section{Acknowledgements}

We thank Yuki Kasai for providing petroleum-contaminated seawater in the beach-simulation tank during the bioremediation experiments and Midori Satoh for technical assistance. We also thank Professor Dr Hans G. Trüper for help with the Latin nomenclature. This work was supported by the New Energy and Industrial Technology Development Organization (NEDO).

\section{References}

Beveridge, T. J., Popkin, T. J. \& Cole, R. M. (1994). Electron microscopy. In Methods for General and Molecular Bacteriology, pp. 42-71. Edited by P. Gerhardt, R. G. E. Murray, W. A. Wood \& N. R. Krieg. Washington, DC: American Society for Microbiology.

Dutta, T. K. \& Harayama, S. (2000). Fate of crude oil by the combination of photooxidation and biodegradation. Environ Sci Technol 34, 1500-1505.

Dyksterhouse, S. E., Gray, J. P., Herwig, R. P., Lara, J. C. \& Staley, J. T. (1995). Cycloclasticus pugetii gen. nov., sp. nov., an aromatic 
hydrocarbon-degrading bacterium from marine sediments. Int J Syst Bacteriol 45, 116-123.

Ezaki, T., Hashimoto, Y. \& Yabuuchi, E. (1989). Fluorometric deoxyribonucleic acid-deoxyribonucleic acid hybridization in microdilution wells as an alternative to membrane filter hybridization in which radioisotopes are used to determine genetic relatedness among bacterial strains. Int J Syst Bacteriol 39, 224-229.

Kasai, Y., Kishira, H. \& Harayama, S. (2002). Bacteria belonging to the genus Cycloclasticus play a primary role in the degradation of aromatic hydrocarbons released in a marine environment. Appl Environ Microbiol 68, 5625-5633.

Katayama-Fujimura, Y., Komatsu, Y., Kuraishi, H. \& Kaneko, T. (1984). Estimation of DNA base composition by high performance liquid chromatography of its nuclease P1 hydrolysate. Agric Biol Chem 48, 3169-3172.

Kodama, Y. \& Watanabe, K. (2003). Isolation and characterization of a sulfur-oxidizing chemolithotroph growing on crude oil under anaerobic conditions. Appl Environ Microbiol 69, 107-112.

Kodama, Y., Ha, L. T. \& Watanabe, K. (2007). Sulfurospirillum cavolei sp. nov., a facultatively anaerobic sulfur-reducing bacterium isolated from an underground crude oil storage cavity. Int J Syst Evol Microbiol 57, 827-831.

Liu, C., Wu, Y., Li, L., Ma, Y. \& Shao, Z. (2007). Thalassospira xiamenensis sp. nov. and Thalassospira profundimaris sp. nov. Int $J$ Syst Evol Microbiol 57, 316-320.

López-López, A., Pujalte, M. J., Benlloch, S., Mata-Roig, M., Rosselló-Mora, R., Garay, E. \& Rodríguez-Valera, F. (2002). Thalassospira lucentensis gen. nov., sp. nov., a new marine member of the $\alpha$-Proteobacteria. Int J Syst Evol Microbiol 52, 1277-1283.
Murray, M. G. \& Thompson, W. F. (1980). Rapid isolation of high molecular weight plant DNA. Nucleic Acids Res 8, 4321-4325.

Orphan, V. J., Hinrichs, K.-U., Ussler, W., III, Paull, C. K., Taylor, L. T., Sylva, S. P., Hayes, J. M. \& Delong, E. F. (2001). Comparative analysis of methane-oxidizing archaea and sulfate-reducing bacteria in anoxic marine sediments. Appl Environ Microbiol 67, 1922-1934.

Smibert, R. M. \& Krieg, N. R. (1994). Phenotypic characterization. In Methods for General and Molecular Bacteriology, pp. 607-655. Edited by P. Gerhardt, R. G. E. Murray, W. A. Wood \& N. R. Krieg. Washington, DC: American Society for Microbiology.

Sohn, J. H., Kwon, K. K., Kang, J.-H., Jung, H.-B. \& Kim, S.-J. (2004). Novosphingobium pentaromativorans sp. nov., a high-molecular-mass polycyclic aromatic hydrocarbon-degrading bacterium isolated from estuarine sediment. Int J Syst Evol Microbiol 54, 1483-1487.

Stackebrandt, E. \& Ebers, J. (2006). Taxonomic parameters revisited: tarnished gold standards. Microbiol Today 33, 152-155.

Thompson, J. D., Higgins, D. G. \& Gibson, T. J. (1994). CLUSTAL W: improving the sensitivity of progressive multiple sequence alignment through sequence weighting, position-specific gap penalties and weight matrix choice. Nucleic Acids Res 22, 4673-4680.

Watanabe, K., Watanabe, K., Kodama, Y., Syutsubo, K. \& Harayama, S. (2000). Molecular characterization of bacterial populations in petroleum-contaminated groundwater discharged from underground crude oil storage cavities. Appl Environ Microbiol 66, 4803-4809.

Wayne, L. G., Brenner, D. J., Colwell, R. R., Grimont, P. A. D., Kandler, O., Krichevsky, M. I., Moore, L. H., Moore, W. E. C., Murray, R. G. E. \& other authors (1987). International Committee on Systematic Bacteriology. Report of the ad hoc committee on reconciliation of approaches to bacterial systematics. Int J Syst Bacteriol 37, 463-464. 